\title{
The Political Consequences of Self-Insurance: Evidence from Central-Eastern Europe, the Caucasus and Central Asia
}

\author{
Katerina Tertytchnaya ${ }^{1}$ - Catherine E. De Vries ${ }^{2}$
}

Published online: 20 July 2018

(c) The Author(s) 2018

\begin{abstract}
Does self-insurance, such as access to savings or assets, affect support for government? While existing research recognizes that households' ability to privately manage income risk and economic uncertainty influences voter redistributive preferences, we know relatively little about how self-insurance affects evaluations of government in the first place. To gain traction on this question, we combine crosssectional and panel public opinion surveys from 28 countries in Central Eastern Europe, the Caucasus and Central Asia with macro-data on economic performance. Exploiting variation in citizen responses to the Great Recession, we show that by enabling citizens to smooth consumption, self-insurance affects how they form economic perceptions. Moreover, we find that self-insurance bolsters support for incumbents. Results allow us to better understand why economic downturns may not dampen support for government, even when economic hardship is rife and access to public safety nets is limited.
\end{abstract}

Keywords Public opinion $\cdot$ Economic perceptions $\cdot$ Self-insurance $\cdot$ Central-Eastern Europe $\cdot$ The Caucasus and Central Asia $\cdot$ Russia

\footnotetext{
The authors wish to thank Ben Ansell, Ryan Carlin, Elias Dinas, David Doyle, Gwen Sasse and Hector Solaz for commenting on previous drafts of this paper as well as two anonymous reviewers and the editor of Political Behavior for their excellent suggestions on how to improve the manuscript. All the data and replication code have been made publicly available and can be downloaded directly from the Political Behavior Dataverse page, see https://doi.org/10.7910/DVN/4SIEEF.
}

Electronic supplementary material The online version of this article (https://doi.org/10.1007/s1110 9-018-9482-4) contains supplementary material, which is available to authorized users.

Catherine E. De Vries

c.e.de.vries@vu.nl

Katerina Tertytchnaya

katerina.tertytchnaya@politics.ox.ac.uk

1 Department of Politics and International Relations, University of Oxford, Oxford, UK

2 Department of Political Science and Public Administration, Vrije Universiteit Amsterdam, Amsterdam, The Netherlands 


\section{Introduction}

In the past decades the cost of protecting against income risks has largely shifted from society as a whole to individuals (Brooks 2009; World Bank 2011). Trends toward privatization, austerity, and fiscal constraints have encouraged poorer and richer households around the world to engage in self-insuring behaviours (Brooks 2014; Gill and Ilahi 2000; Ehrlich and Becker 1972; Carroll 1997). ${ }^{1}$ By accumulating precautionary savings, investing in risk-hedging assets, and ensuring access to monetary and non-monetary help from friends and family at home or abroad, households aim to insure against economic risk and compensate for income loss in the event of an economic downturn. It is estimated that in 2007-2009 alone precautionary savings, that is savings set aside in response to news about the looming recession, accounted for at least two-fifths of the increase in household saving rates (Mody et al. 2012). Self-insurance also enabled many households to smooth consumption, especially in regions where access to state-funded safety nets was limited. For example, in the South Caucasus, where just seven per cent of crisis-affected citizens had access to state-provided insurance, one in two households actively relied on private safety nets in order to compensate for income loss during the Great Recession (EBRD 2011).

The contemporary importance of self-insurance, commonly defined as the actions taken by individuals or households in order to reduce the size of economic uncertainty, or of a potential income loss (Ehrlich and Becker 1972), has reinvigorated scholarly interest in the political consequences of households' risk-management decisions. While existing research recognizes self-insurance effects on voter welfare, redistributive preferences (Ansell 2014; Doyle 2015; Hacker et al. 2013; Rehm et al. 2012) and political engagement (Escribà-Folch et al. 2015; Brooks 2014; McMann 2006), we know relatively little about how private safety nets affect attitudes towards government in the first place. Could households' ability to manage economic risk and uncertainty affect not only what citizens want from government, but also how they evaluate the government to be performing in the first place? To put this point in starker terms, consider a hypothetical case of two otherwise similar individuals, one with and the other without access to self-insurance, in the form of precautionary savings for example. The question that arises then is whether a deterioration in economic conditions will have the same effect on these two individuals' support for government.

Drawing on research on political economy and economic voting, this article sheds light on the relationship between self-insurance and support for government. We propose that self-insurance could influence how citizens form economic perceptions, and subsequently how they evaluate the government to be performing. We anticipate that by increasing protection against economic risk and enabling households to smooth consumption in the event of an economic downturn, self-insurance could increase satisfaction with household finances and national economic conditions.

\footnotetext{
1 We use the terms self-insurance, private safety nets and household economic buffers interchangeably. All these represent households' ability to privately manage income and economic risks.
} 
Similarly, we anticipate that consistent with evidence that voter assessments of economic performance inform government approval and the vote, households with access to private safety nets could report improved assessments of government performance. By relying on their pocketbooks to infer how the economy and by extension the national government are performing, however, voters may be crediting incumbents for their own decisions to manage economic uncertainty. This may be the case even in contexts where insurance markets, that could step in to compensate for income loss and economic hardship, are incomplete (Carroll and Kimball 2008; Carroll 1997), or where welfare markets are lacking all together (Gill and Ilahi 2000). These propositions are consistent with evidence that in more and less democratic regimes, assessments of economic performance inform voter attitudes toward government and the vote more broadly (Lewis-Beck and Stegmaier 2009; Tilley et al. 2018; Campello and Zucco 2015).

To empirically test our theoretical propositions, we draw on a wealth of crosssectional and panel datasets of approximately 40,000 respondents from 28 countries and combine them with data on national and regional growth and unemployment. The first part of the empirical analysis relies on cross-sectional survey data collected as part of the 2010 round of the Life in Transition survey (LITS II). This survey, commissioned by the European Bank for Reconstruction and Development (EBRD), was administered in Central Eastern Europe, the Caucasus and Central Asia, shortly after the Great Recession (EBRD 2011). In a second step, we complement crossnational evidence with rich panel data from Russia. The Russian Longitudinal Monitoring survey (RLMS) tracks the same individuals over time and allows us to document in greater detail how self-insurance affects economic perceptions (National Research University, NRU Higher School of Economics, HSE Demoscope et al. 2011). In repeated interviews, the RLMS collects information about citizens' ability to weather the effects of economic and labour market insecurity and documents their evaluations of household and regional economic conditions.

To preview the results, we find robust effects of self-insurance on economic perceptions and political support. Drawing on evidence from a period when many countries in Central-Eastern Europe, the Caucasus and Central Asia were still experiencing the consequences of the Great Recession, the analysis shows that by offering households protection against economic risk and enabling them to smooth consumption in the event of income loss, self-insurance may ameliorate economic assessments and improve evaluations of government performance. As the analysis shows, the probability that households affected by the Great Recession would reduce consumption or cut down on utility payments as a result of the downturn was approximately $70 \%$ lower among households with access to savings than among households also affected with the recession, but who lacked access to private safety nets. These results are shown to be robust to a broad range of empirical specifications. Moreover, to address concerns regarding the relationship between government support and access to self-insurance, we show that the political consequences of private safety nets are not limited to government supporters alone.

The article's findings have important implications. Drawing on novel survey evidence from a large sample of countries, our results engage with on-going debates regarding the political consequences of private safety nets whether remittances 
(Doyle 2015; Ahmed 2017; Tertytchnaya et al. 2018) or religiosity (Popova 2014; Clark and Lelkes 2005), and extend the agenda to consider how self-insurance affects voters' economic evaluations and political attitudes. Second, our findings contribute to a growing literature concerned with the effect of economic (in)security on social policy preferences (Rehm et al. 2012; Hacker et al. 2013; Doyle 2015; Ansell 2014). The results reveal that in more and less liberal democracies, private safety nets have political ramifications beyond the realm of social policy. Third, our analysis speaks to a strand in the economic voting literature which underlines how cross-nationally, statist economic policy regimes and generous social security systems condition the effect of macroeconomic deterioration on turnout, government approval and the vote (Carlin and Hellwig 2015; Pacek and Radcliff 1995; Singer 2011). As we illustrate below, just like statist policy regimes have been found to protect voters from economic downturns, private safety nets can also ameliorate support for the government. Shedding light on the mechanisms through which self-insurance influences political attitudes can also go a long way towards explaining why economic downturns may not always affect government approval, even in contexts where economic hardship is rife, and access to public safety nets is limited (e.g. Kriesi 2012; Hernandez and Kriesi 2015).

\section{The Importance of Self-Insurance}

In economics and political science, the concept of self-insurance is often used to describe actions taken by individuals or households in order to reduce the size of economic uncertainty, or a potential income loss. The expectation is that households facing a situation of risk, such as loss of income, can redistribute income from a good state to a bad one (for example from employment to unemployment) as a form of assistance for possible 'rainy days' to come (Ehrlich and Becker 1972; Brooks 2014). Self-insurance therefore encompasses private, i.e. household-based, or social safety nets, and stands in contrast to public safety nets, or state-provided social insurance.

Existing scholarship shows that self-insurance has important implications for household-level economic outcomes. Monetary and non-monetary support from friends and family at home and abroad (Harknett 2006; Doyle 2015), assets such as housing (Ansell 2014) and religious networks (Popova 2014; Clark and Lelkes 2005), have been found to ameliorate household well-being, and increase protection against transitory income loss. In the political realm, self-insurance has been found to dampen individual-level demand for redistribution on the one hand, and aggregate-level social spending on the other (Doyle 2015; Ansell 2014). Moreover, recent research has documented a link between self-insurance and the decision to engage in politics. Drawing on empirical evidence from Brazil for example, Sarah Brooks (2014) has shown that citizens lacking the means to insure against livelihood risks are more likely to shy away from active political engagement. Yet, we still know relatively little about how private safety nets affect not only what citizens want from government and how they express their grievances, but also how they evaluate government performance in the first place. By studying the individual-level 
mechanisms that drive the connection between self-insurance and political support, this study hopes to expand our understanding.

At the aggregate level, comparative research advances the view that the 'cushion' provided by private safety nets has often ensured political stability in Sub-Saharan Africa, East Asia, Eastern Europe and Latin America (e.g. Cheng and Gereffi 1994; Diaz 1993; Meagher 1995, Greskovits 1998). In recent years, Ahmed (2012, 2017) has provided compelling evidence that far from empowering political mobilization (De la Garza and Hazan 2003), private safety nets in the form of unearned foreign income can reduce government turnover. While this literature recognises self-insurance effects on government stability, we still know relatively little about the microlevel mechanisms that drive the political consequences of self-insurance and could influence the connection between household safety nets and political support.

Our work finally takes cue from studies showing that the importance of economic dislocation in shaping political attitudes is not constant, but conditional on risk protection mechanisms. In the transition countries of Central-Eastern Europe, the Caucasus and Central Asia, for example, religion, just like unearned income received from abroad have been found to buffer the well-being impact of economic reforms on political assessments (Popova 2014; Tertytchnaya et al. 2018). In Western countries, employment protection legislation has also been shown to dampen the importance of individual-level risk in shaping policy preferences (Gingrich and Ansell 2012; Rehm et al. 2012). Similarly, statist policy regimes have been linked to whether people vote on the one hand, and to how they factor objective economic indicators in their vote calculus on the other (Carlin and Hellwig 2015; Pacek and Radcliff 1995; Singer 2011). We draw on these insights to explain how self-insurance could influence voter perceptions of economic performance and evaluations of government performance. Governments' approval function, existing research shows, serves as important proxy for a continual accountability mechanism in democracies (Carlin et al. 2014; Carlin and Hellwig 2015) and non-democracies alike (Colton and Hale 2009; Frye et al. 2017; Treisman 2011), shaping governments' electoral strategies, legislative agendas and policy choices.

\section{The Political Consequences of Self-Insurance}

We advance three claims. First, we argue that self-insurance influences how citizens form economic perceptions. Specifically, we expect that voters with access to private safety nets will report better assessments of household finances, or pocketbook economic conditions than their counterparts, everything else equal. This is because private safety nets offer households protection against economic risk and enable them to smooth consumption in the event of income loss. More specifically, we expect that by reducing household exposure to the vagaries of the business cycle, and allowing citizens to smooth consumption in the event of transitory income loss, private safety nets reduce economic insecurity-or the 'psychologically mediated experience of inadequate protection against hardship-causing economic risks' (Rehm et al. 2012; Hacker et al. 2014). Unemployment, or wage reductions for example, should be less feared when households know that in the event of a 'rainy day', they will be able to 
either draw on existing savings, or that they will have access to help from friends and family (Carroll 1997). Similarly, during periods of transitory income loss private safety nets could actively help households to smooth consumption (Ansell 2014), and keep up with utility payments (Gill and Ilahi 2000).

Second, we suggest that the economic optimism self-insurance generates at the household level translates into more positive assessments of the state of the national economy. As existing literature reminds us, variation in personal economic circumstances often drives heterogeneity in perceptions of national economic performance. Individuals or groups experiencing economic hardship, for example, have been consistently shown to report more pessimistic sociotropic evaluations than their counterparts (Anderson 2007; Weatherford 1983). In conclusion, much like partisanship has been repeatedly shown to influence people's economic evaluations (e.g. Johnston 2006), we anticipate that self-insurance also influences the way citizens evaluate macro-economic performance.

Finally, we expect that self-insurance may ameliorate evaluations of government. Concretely, we expect that individuals with access to risk-hedging assets, savings and networks will exhibit more favourable attitudes toward government relative to their counterparts, an effect that operates through improved economic assessments. Compared to their counterparts who lack access to means of self-insurance, more economically secure individuals are more likely to report positive evaluations of incumbent performance, even when the economy deteriorates. In this context, voters who rely on their pocketbook to infer how well or poorly the national economy and the incumbent are performing, may be crediting incumbents for their own household's decision to manage economic risk and uncertainty. This could be true of voters even in countries where insurance markets are incomplete (Carroll and Kimball 2008; Carroll 1997), or where state-provided social protection, in the form of unemployment insurance for example, is lacking (Gill and Ilahi 2000). This proposition is in line with studies on economic voting. As existing research shows, in developed and developing economies, voters often rely on their pocketbooks to infer how the government, or the incumbent, are performing (Campello and Zucco 2015; Rosenfeld 2018; Duch and Stevenson 2008; Healy and Malhotra 2012; Lewis-Beck and Stegmaier 2009; Tilley et al. 2018). Finally, the argument is in line with recent scholarship on patrimonial voting, which argues that the possession of high- or lowrisk assets affects support for right and left-wing parties respectively (Nadeau et al. 2011; Lewis-Beck and Nadeau 2011; Persson and Martinsson 2016).

Yet, when voters infer that the national economy, and by extension the government, is performing well because they can buffer the effects of an ongoing downturn, accountability mechanisms could erode, especially in contexts we study here in which these mechanisms are rudimentary to begin with. Rewarding incumbents for household decisions to manage economic risk and uncertainty, or for adjusting monthly consumption habits so that it is possible to set money aside for a 'rainy day', may undermine the link between government action, voters and electoral sanctions (e.g. Campello and Zucco 2017). When a government enjoys high approval in the midst of an economic downturn, it may be less incentivized to invest in policies aimed at enhancing social welfare or providing social assistance to the most vulnerable (e.g. Tertytchnaya et al. 2018). Such a breach 
in the accountability mechanism comes with important implications. As existing literature reminds us, in more and less liberal regimes, economic voting, i.e. voters' ability to reward or punish incumbents on the basis of how well or poorly the economy is performing, is a key mechanism to ensure responsive and accountable governance (Campello and Zucco 2015; Stokes 2001).

It is worth briefly considering a number of potential qualifications to the argument we propose. To begin with, a note on the connection between wealth and self-insurance is warranted. Wealth, or the ownership of financial and non-financial assets, such as savings (a form of liquid assets) stocks, houses or land, may be considered as a particular sub-type of self-insurance. Ansell (2014) for example argues that homeownership acts as a form of self-insurance against the welfare losses associated with job loss, especially when access to credit may be curtailed. Assets may be converted into income through sale or by borrowing against them as collateral in order to smooth consumption (Ansell 2014; Nadeau et al. 2011). Yet, if individuals are unable to borrow against or sell any of the material assets they possess, such as their home for example, they do not see the realised value of those assets as self-insurance. In other words, assets are an economic buffer, or a means of self-insurance, for individuals who are able to either borrow against their assets or to sell them in order to receive consumption-smoothing income.

We also assume that access to self-insurance is not exclusively available to government supporters alone. Whether certain households across countries or sub-national units in the same country have access to various private safety nets, such as help from friends and relatives at home and abroad, while others do not, is an outcome that national governments do not fully control. Access to private safety nets does not necessarily dependent on citizens' political affiliations, or pre-existing support for government. Similarly, means of private insurance are accessible to poorer and richer households alike. While the amount and value of certain private safety nets, such as savings, could be endogenous to individuals' economic circumstances (Carroll and Kimball 2008), access to risk-insuring private safety nets is largely independent of individuals' temporary or labour market income (e.g. Ansell 2014, p. 385). Existing research shows that measures of individual or household income do not necessarily capture households' ability to buffer the effects of economic dislocation (Hacker et al. 2013). In line with existing literature in economics, we also acknowledge that the extent to which it can protect households from economic dislocation depends on various factors. The nature of the downturn the economy is facing is one of them. Household savings will better protect individuals from income loss when economic deterioration is not accompanied by high levels of inflation (e.g. Ansell 2014). But while some types of private safety nets, such as precautionary savings, decline as a function of the duration and size of economic shocks households experience, other forms of self-insurance, such as monetary assistance from friends or family at home and abroad, could in fact be counter-cyclical to individuals' economic conditions. These propositions are well in line with the theoretical core of our argument. Yet, given that we propose a general argument on the political consequences of selfinsurance, investigating heterogeneity in types of private safety nets falls beyond the scope of this study. 


\section{Background and Case Selection}

To test the proposition that self-insurance increases support for government, and that such an effect stems from an economic voting mechanism, we rely on evidence from Europe, the Caucasus, and Central Asia. ${ }^{2}$ Countries in the region were greatly affected by the Great Recession and provide a critical setting against which to explore the effects of private safety nets on political attitudes for several reasons.

First of all, self-insurance has been traditionally important in this part of the world. Focusing on Russia alone, Richard Rose and his co-authors for example, have shown that when the costs of economic transformation were at a peak in 1996, only $15 \%$ of Russians were relying solely on earnings from employment. This figure was no higher at the height of the economic boom a decade later (Rose et al. 2011). Moreover, in the period preceding the Great Recession, revisions of growth projections and elevated uncertainty coincided with the increase in precautionary saving rates across the region. During the Great Recession, households in Central Eastern Europe, the Caucasus and Central Asia extensively relied on private safety nets to weather the effects of income loss (ERBD 2011). Reliance on self-insurance resulted to a great extent from the fact that access to welfare provisions was limited for the majority of countries. The EBRD for example estimates that social assistance programs, income support and unemployment insurance covered just over $20 \%$ of all crisis-affected households in the region (ERBD 2011). Moreover, because of fiscal constraints, some governments had to implement measures that actually reduced, rather than increased unemployment insurance. Last Resort Social Assistance Programmes (LRSA), adopted in response to the downturn, only covered a small share of the population (World Bank 2011).

In terms of the empirical analysis, the fact that we focus on a period of economic contraction, helps us further isolate the political consequences of self-insurance. If we had tested how private safety nets influence economic and political assessments during a period of growth, it would have been more difficult to disentangle whether the positive returns of self-insurance on approval were not the result of the government's positive management of state finances. Around the Great Recession, however, households invested in self-insurance and accumulated precautionary savings largely because they were concerned about the looming economic downturn, not because economic performance was good. This is directly relevant to our analysis, which proposes that by reducing voters' exposure to the vagaries of the business cycle, self-insurance colours economic, and by extension political assessments. As countries in the region we focus on here were some of the worst hit by

\footnotetext{
2 The analysis relies on evidence from the following countries: Albania, Armenia, Azerbaijan, Belarus, Bosnia and Herzegovina, Bulgaria, Croatia, the Czech Republic, Estonia, Georgia, Hungary, Kazakhstan, Kosovo, the Kyrgyz Republic, Latvia, Lithuania, the Former Yugoslavian Republic of Macedonia, Moldova, Montenegro, Poland, Romania, Russia, Serbia, the Slovak Republic, Slovenia, Tajikistan, Ukraine and Uzbekistan. These countries share the experience of post-Soviet transitions, but also present variation in terms of their political record. While in 2010 Estonia and Slovenia were well functioning liberal democracies for example, Turkmenistan and Uzbekistan in Central Asia were two of all 47 countries in the world ranked 'Not Free' according to Freedom House.
} 
the Great Recession, the case selection makes it particularly difficult to actually find that private safety nets influence economic and political evaluations. According to the World Bank for example, in 2009 Latvia's annual GDP growth was negative, at - 14.25. As an influential literature shows, the salience voters attach to the economy closely tracks changing conditions. Economic downturns make citizens more apt to judge incumbents based on performance and to hold them accountable for failures (Singer 2011; Singer and Carlin 2013). When economic dislocation is rife, it is very difficult for citizens to ignore.

\section{Empirical Results}

In this section, we test our conjectures about the connection between self-insurance and support for government using cross-national survey data from the 2010 EBRD Life in Transition Survey (LITS II), and panel data from Russia. Summary statistics for the surveys used in this paper are provided in Tables A1 and A2 in the Appendix.

\section{Evidence from Cross-National Survey Data}

We begin by testing our conjectures about the political consequences of self-insurance using cross-national survey data from the 2010 Life in Transition Survey. While most countries in Central-Eastern Europe, the Caucasus and Central Asia were still experiencing the aftershocks of the Great Recession, the ERBD administered an identical set of nationally representative surveys in many countries in the region. As the surveys were designed to capture the effects of the Great Recession, they include a very detailed set of questions that tap into people's economic and political preferences. These survey items allows us to design well-specified models.

The empirical analysis presented below focuses on households across 28 countries included in the survey (see footnote 1) and captures access to self-insurance by a survey question asking if 'at the end of a typical month, households have anything left over to put into savings' (coded as 1 ) or not (coded as 0$).{ }^{3}$ We estimate the effect of self-insurance, which we proxy here with the help of the savings indicator, on economic assessments and evaluations of government performance. The two economic variables we rely on ask respondents to evaluate whether on the whole, they are satisfied with their financial situation on the one hand, and with the present state of the economy on the other hand. Respondents are also asked to evaluate how the government is performing. All outcome variables are measured on a 5-point scale

\footnotetext{
3 The question available in the Life in Transition surveys asks whether households have money to set aside, and how much money they set aside, not whether they place savings in a bank account alone. Indeed, only about $60 \%$ of households, who can set money aside, report to own a bank account. In Tables $\mathrm{C} 3 \mathrm{~A}, \mathrm{C} 3 \mathrm{~B}$ and $\mathrm{C} 3 \mathrm{C}$ in the Appendix we also probe the robustness of these results using quantiles of reported savings' amounts instead.
} 
with higher values denoting greater satisfaction with economic conditions and government performance. ${ }^{4}$

In addition to standard demographic controls, such as age, gender, marital status, employment and education, models presented below control for household wealth. The wealth index considers whether households have access to tap water, electricity, fixed telephone line, central heating and to the internet, as well as whether households own a secondary residence, a car and a computer. The first set of items describe household characteristics, while the final three items capture durable assets. Combining these items, and employing Principal Component Analysis, we implement a weighting system for constructing the wealth index. From this, we extract the first component which we use for the analysis (e.g. Cordova 2009). Attitudes towards risk in general are also controlled for, ${ }^{5}$ as theories of choice under uncertainty suggest that risk-acceptant individuals are more likely discount economic risk (e.g. Brooks 2014), and possibly less likely to insure. ${ }^{6}$ Finally, models control for country economic, and democratic performance. Economic performance data on economic growth (GDP growth, annual percentage for 2010) come from the World Bank, while the democratic performance indicator, also for 2010, comes from the Freedom House political rights index. This indicator, which ranges on a scale from 1 to 40, assigns higher scores to more democratic countries, and captures whether there is political pluralism and participation in a country, as well as open and free private discussion (Freedom House 2010). Political pluralism and participation are of critical importance for enabling opposition forces and the media to articulate blame for an economic downturn.

The cross-national analysis proceeds in three steps. First, we investigate the effect of savings on household coping strategies in light of the recession. Second, we estimate self-insurance effects on assessments of the economy and government performance. Finally, to shed light on the full mechanism that links self-insurance to economic evaluations and from there to government approval, we employ a causal mediation framework (Becher and Donnelly 2013; Imai et al. 2010a, b; Rosenfeld 2018). This approach allows us to explore how much of the total effect of self-insurance on political assessments is mediated by economic evaluations. All models presented below use mixed effects regressions, suitable for multilevel data. Multilevel statistical techniques allow us to jointly model the macro-level and individual level determinants of household coping strategies, economic and political assessments,

\footnotetext{
${ }^{4}$ In Table $\mathrm{C} 2$ of the Appendix, we show that in line with the argument, savings also ameliorate trust in government, the parliament and the President.

${ }^{5}$ The question which taps into people's attitudes towards risk in the LITS survey presents respondents with a hypothetical scenario that is very well-suited to capturing attitudes towards risk, or propensity to save. More specifically, the surveys ask respondents to decide whether 'if they had been a farmer, they would sell their car and buy an irrigation system that would protect their harvest in the case of a drought, or instead take the risk and hope there is no drought'.

${ }^{6}$ All models are robust to the inclusion of controls for household income and crisis exposure. Please see Tables $3 \mathrm{C}$ in the Appendix. The income indicator asks respondents to place their households on a 10-step income scale, from poorer to richer. The risk exposure variable, which captures whether households were affected by the recession, is coded as (1) if households were to any extend affected by the economic downturn in the last 2 years, and ( 0$)$ if they were not.
} 
and to estimate separate variance structures in order to produce unbiased standard errors. Moreover, country specific random intercepts help to reduce the threat of omitted variable bias from unobserved country characteristics. ${ }^{7}$

\section{Self-Insurance and Economic Assessments}

Table 1 below investigates the micro-foundations of the proposition that self-insurance ameliorates economic evaluations. It examines whether among those households negatively affected by the Great Recession of 2008-2010, savings' holders were less likely to reduce consumption on the one hand, and delay payment on utilities on the other. Overall, around $72 \%$ of all surveyed households report to have been to a various extent affected by the economic downturn. While existing literature proposes that self-insurance enables households to smooth consumption during periods of transitory income loss, there are very few empirical tests of this hypothesis.

As we show in Table 1, holding everything else constant, the probability that households affected by the Great Recession will reduce consumption is $71 \%(95 \%$ CI $-0.79,-0.64)$ lower among households with access to savings than among households also affected with the recession, but who lack access to savings. Households with savings are also by $74 \%$ less likely to cut down on utility payments when compared to their counterparts $(95 \% \mathrm{CI}-0.85,-0.63)$. What is more, the 'consumption smoothing' effect of self-insurance is robust to the inclusion of controls for individual-level wealth, and macro-level controls for economic, and democratic performance. Overall, evidence provided in Table 1, provides support for the argument that self-insurance enables households negatively affected by an economic downturn to smooth consumption, and reduces exposure to the vagaries of the economy.

Table 2 takes the analysis a step further. Model 1 tests for the effect of savings on satisfaction with household economic conditions, and Model 2 tests for the effect of savings on satisfaction with national economic performance instead. In line with our expectations, the results in Table 2 illustrate that individuals who at the end of a typical month were able to set some money aside will, everything else equal, hold more favourable evaluations of household, and national economic performance. Selfinsurance effects are larger in Model 1, which considers satisfaction with household finances. Among respondents who could save, predicted satisfaction with household finances is around 3.1 (95\% CI 2.98, 3.22), with the dependent variable measured on a 5-point scale. Predicted satisfaction with household finances is by 0.61 (95\% CI $0.58,0.65)$ lower among respondents without access to savings. Such differences are less pronounced when we consider assessments of macro- economic performance. While predicted satisfaction among savings' holders is around 2.66 (95\% CI 2.56, 2.76), satisfaction with economic performance is lower by 0.33 (95\% CI $0.30,0.37$ ) among respondents without savings.

\footnotetext{
7 In Section C1 of the Appendix, we further show that the results remain robust when we use random slopes for savings. Random slopes allow us to account for the fact that the effect of self-insurance could vary across countries.
} 
Table 1 Private safety nets enable households to smooth consumption. Source: LITS 2010

\begin{tabular}{|c|c|c|}
\hline & $\begin{array}{l}\text { (1) } \\
\text { Reduced consump- } \\
\text { tion }\end{array}$ & $\begin{array}{l}\text { (2) } \\
\text { Cut down on utility } \\
\text { payments }\end{array}$ \\
\hline Has savings & $\begin{array}{l}-0.717 * * * \\
(0.041)\end{array}$ & $\begin{array}{l}-0.741 * * * \\
(0.055)\end{array}$ \\
\hline Wealth index & $\begin{array}{l}-0.214 * * * \\
(0.013)\end{array}$ & $\begin{array}{l}-0.070 * * * \\
(0.016)\end{array}$ \\
\hline Age & $\begin{array}{l}0.089 * * * \\
(0.018)\end{array}$ & $\begin{array}{l}-0.208 * * * \\
(0.022)\end{array}$ \\
\hline Male & $\begin{array}{l}-0.091 * * * \\
(0.032)\end{array}$ & $\begin{array}{l}-0.062 \\
(0.040)\end{array}$ \\
\hline Co-habiting & $\begin{array}{l}-0.026 \\
(0.033)\end{array}$ & $\begin{array}{l}0.008 \\
(0.041)\end{array}$ \\
\hline Education & $\begin{array}{l}-0.193 * * * \\
(0.028)\end{array}$ & $\begin{array}{l}-0.178 * * * \\
(0.034)\end{array}$ \\
\hline Employed & $\begin{array}{l}-0.048 \\
(0.035)\end{array}$ & $\begin{array}{l}0.203 * * * \\
(0.043)\end{array}$ \\
\hline Risk acceptant & $\begin{array}{l}-0.012 \\
(0.032)\end{array}$ & $\begin{array}{l}-0.047 \\
(0.040)\end{array}$ \\
\hline Growth & $\begin{array}{l}-0.057 \\
(0.044)\end{array}$ & $\begin{array}{l}-0.058 \\
(0.038)\end{array}$ \\
\hline Democracy & $\begin{array}{l}-0.006 \\
(0.010)\end{array}$ & $\begin{array}{l}-0.012 \\
(0.009)\end{array}$ \\
\hline Constant & $\begin{array}{l}-0.466^{* * * *} \\
(0.101)\end{array}$ & $\begin{array}{l}-1.745^{* * *} \\
(0.088)\end{array}$ \\
\hline Log Likelihood & $-12,015.26$ & -8679.486 \\
\hline AIC & $24,054.53$ & $17,382.97$ \\
\hline $\mathrm{BIC}$ & $24,149.24$ & $17,477.68$ \\
\hline Respondents & 19,775 & 19,775 \\
\hline Countries & 28 & 28 \\
\hline
\end{tabular}

Notes: Table entries are multilevel logit regression coefficients with standard errors in parentheses. The sample is restricted to respondents who were affected by the Great Recession, as only respondents who reported to be affected by the crisis were asked how they coped with its consequences

Significant at the $* \mathrm{p}<0.10, * * \mathrm{p}<0.05, * * * \mathrm{p}<0.01$ level

Additional controls designed to capture the effect of household economic circumstances, and isolate the effect of savings on the outcome variables, also point to the direction theoretically anticipated. The wealth indicator has a direct and positive effect on assessments of household and national economic performance. And while the growth indicator fails to reach statistical levels of significance in Model 1, it is positive and statistically significant in Model 2, which predicts assessments 
Table 2 Self-insurance effects on economic assessments. Source: LITS 2010
(1)

(2)

Household economic satisfaction
National economic satisfaction

\begin{tabular}{|c|c|c|}
\hline \multirow[t]{2}{*}{ Has savings } & $0.615^{* * *}$ & $0.334 * * *$ \\
\hline & $(0.018)$ & $(0.017)$ \\
\hline \multirow[t]{2}{*}{ Wealth index } & $0.101 * * *$ & $0.029 * * *$ \\
\hline & $(0.006)$ & $(0.006)$ \\
\hline \multirow[t]{2}{*}{ Age } & 0.011 & -0.011 \\
\hline & $(0.008)$ & $(0.008)$ \\
\hline \multirow[t]{2}{*}{ Male } & -0.010 & $-0.050^{* * *}$ \\
\hline & $(0.015)$ & $(0.014)$ \\
\hline \multirow[t]{2}{*}{ Co-habiting } & $0.036 * *$ & $-0.030^{* *}$ \\
\hline & $(0.015)$ & $(0.015)$ \\
\hline \multirow[t]{2}{*}{ Education } & $0.097 * * *$ & -0.007 \\
\hline & $(0.013)$ & $(0.012)$ \\
\hline \multirow[t]{2}{*}{ Employed } & $0.072 * * *$ & -0.022 \\
\hline & $(0.016)$ & $(0.015)$ \\
\hline \multirow[t]{2}{*}{ Risk acceptant } & 0.022 & $0.050 * * *$ \\
\hline & $(0.015)$ & $(0.014)$ \\
\hline \multirow[t]{2}{*}{ Growth } & 0.027 & $0.107 * * *$ \\
\hline & $(0.025)$ & $(0.022)$ \\
\hline \multirow[t]{2}{*}{ Democracy } & $-0.011 *$ & $-0.014 * * *$ \\
\hline & $(0.006)$ & $(0.005)$ \\
\hline \multirow[t]{2}{*}{ Constant } & $2.611 * * *$ & $2.446 * * *$ \\
\hline & $(0.059)$ & $(0.051)$ \\
\hline Log Likelihood & $-28,266.22$ & $-27,252.04$ \\
\hline AIC & $56,558.45$ & $54,530.09$ \\
\hline BIC & $56,661.02$ & $54,632.68$ \\
\hline Observations & 19,742 & 19,767 \\
\hline Number of groups & 28 & 28 \\
\hline
\end{tabular}

Notes: Table entries are multilevel regression coefficients with standard errors in parentheses

Significant at the , $* \mathrm{p}<0.10, * * \mathrm{p}<0.05, * * * \mathrm{p}<0.01$ level

of national economic conditions. As growth increases, evaluations of national economic conditions also improve.

As already noted, a key assumption underlying our analysis is that self-insurance could increase economic optimism for both richer, and poorer households. Yet, one might still be concerned that self-insurance is only a proxy for higher household income. To address this concern, we probe the robustness of our results controlling for household income, as well as exposure to the Great Recession. The results, which we present in Tables C3 in the Appendix, remain consistent. Table D1.1 and Figure D1.1 in the Appendix also interact the measure of self-insurance available 
Table 3 Self-insurance, economic assessments, and government approval

\begin{tabular}{llll}
\hline & $(1)$ & $(2)$ & $(3)$ \\
& Without mediators & Pocketbook mediator & Sociotropic mediator \\
\hline Has savings & $0.132 * * *$ & $0.030^{*}$ & $0.053^{* * *}$ \\
& $(0.017)$ & $(0.017)$ & $(0.016)$ \\
Mediators & & $0.164 * * *$ & $0.228^{* * *}$ \\
& & $(0.007)$ & $(0.007)$ \\
Demographic controls & $\checkmark$ & $\checkmark$ & $\checkmark$ \\
Country controls & $\checkmark$ & $\checkmark$ & $\checkmark$ \\
Constant & $2.844 * * *$ & $2.413 * * *$ & $2.285 * * *$ \\
& $(0.061)$ & $(0.061)$ & $(0.058)$ \\
Log Likelihood & $-22,912.71$ & $-22,547.75$ & $-22,350.45$ \\
AIC & $45,851.42$ & $45,123.5$ & $44,728.89$ \\
BIC & $45,952.5$ & $45,232.33$ & $44,837.74$ \\
Individuals & 17,594 & 17,557 & 17,585 \\
Countries & 28 & 28 & 28 \\
\hline
\end{tabular}

Notes: Table entries are multilevel regression coefficients with standard errors in parentheses

Significant at the $* \mathrm{p}<0.10, * * \mathrm{p}<0.05, * * * \mathrm{p}<0.01$ level. Full results presented in Table B1 of the Appendix

in the LITS surveys with the income indicator, while controlling for the individual and country-level covariates presented in Table 2 . These results show that selfinsurance ameliorates economic assessments for poorer, and richer households alike. The effects are substantively important as they suggest that on average, self-insurance makes poorer respondents as satisfied with household and national economic conditions as respondents who place themselves on the higher rung of the threestep income category, yet lack access to savings. Additional tests presented in the Appendix (Section D2), further allow us to show that access to savings does not consistently predict the occurrence of labor market shocks. This is important, as one could argue that already vulnerable households, those who do not have access to self-insurance are the ones who experience labour-market shocks. These results are in line with the experience of the Great Recession across the region: during this period, even public-sector employees, who had stable jobs and higher income, were affected by fiscal constraints and saw their salaries decline. This was particularly the case in countries that had to implement public-sector reforms in an attempt to meet conditionality criteria imposed by the International Monetary Fund.

\section{Self-Insurance, Economic Assessments and Government Approval}

Following up from the analysis presented in Table 2, the analysis in Table 3 tests for self-insurance effects on government approval. The dependent variable asks respondents to rate the overall performance of the national government, ranging from 1 (very bad) to 5 (very good). While Model 1 documents self-insurance 
effects on government evaluations without considering the channels through which self-insurance effects are expected to operate, i.e., economic assessments, Models 2 and 3 estimate the effect of self-insurance on support for government while controlling for economic optimism at the household, and national level respectively (the moderators). According to our theory, self-insurance could have a mediated effect on approval, and this effect would partly flow through assessments of economic performance.

Turning to Model 1, we see that holding everything else constant, government approval is by 0.13 points higher among individuals with access to savings than it is among their counterparts who lack access to self-insurance (95\% CI 0.09, 0.16). For these two groups of respondents, predicted government approval hoovers well above average (around 2.8 and 2.9 respectively), with the dependent variable measured on a 5-point scale. Moving ahead, Models 2 and 3 in Table 3 suggests that self-insurance effects on government approval remain robust, even after we control for each of the moderators, or channels, through which we would expect self-insurance effects on approval to operate, i.e. household and macro-economic optimism. As also anticipated, although statistically significant, the coefficient of self-insurance on approval in Models 2 and 3 is significantly reduced. Model 2 suggests that when we control for the pocketbook mediator, government approval among savings' holders is only by 0.03 greater than among respondents without access to savings. This difference is statistically significant at the 90 percent level. Model 3 similarly suggests that when we control for the sociotropic mediator, i.e. assessments of national economic performance, government approval among savings' holders is by 0.05 greater than it is among respondents without access to savings $(0.05,95 \%$ CI $0.02,0.08)$. The reduction in the size of the savings' coefficient in both models provides some preliminary support for the hypothesis that part of the total effect of self-insurance on approval operates through the economic assessments channel, and at a first step, validates the mediation mechanism. To test this in a more systematic way, we use a causal mediation framework.

Causal mediation analysis allows us to succinctly summarize evidence for the relationships implied in the theory regarding the effect of self-insurance on approval in terms of three types of effects: total effects, average direct effects, and average causal mediation effects. The total effect of self-insurance on approval can be decomposed into a direct, and a mediated effect. The direct effect of savings on evaluations of government performance tells us how much gaining access to savings would cause government approval to shift if assessments of national economic performance, the mediator, did not change. In other words, it captures the effect of self-insurance that does not flow through the economic optimism channel. The mediated effect represents the average change in evaluations of government, through the economic optimism channel, when access to savings, a proxy for self-insurance, changes. In this setup, we are substantively interested in the proportion of the total effect of savings on approval, that is mediated through the economic optimism channel. To estimate these quantities of interest, we use the algorithm specified by Imai et al. (2010a) and implemented in the R package mediation.

Figure 1 summarizes the results. The total effect of savings on government approval (ATE), is roughly equal to 0.13 (95\% CI 0.09, 0.16). The direct effect of 


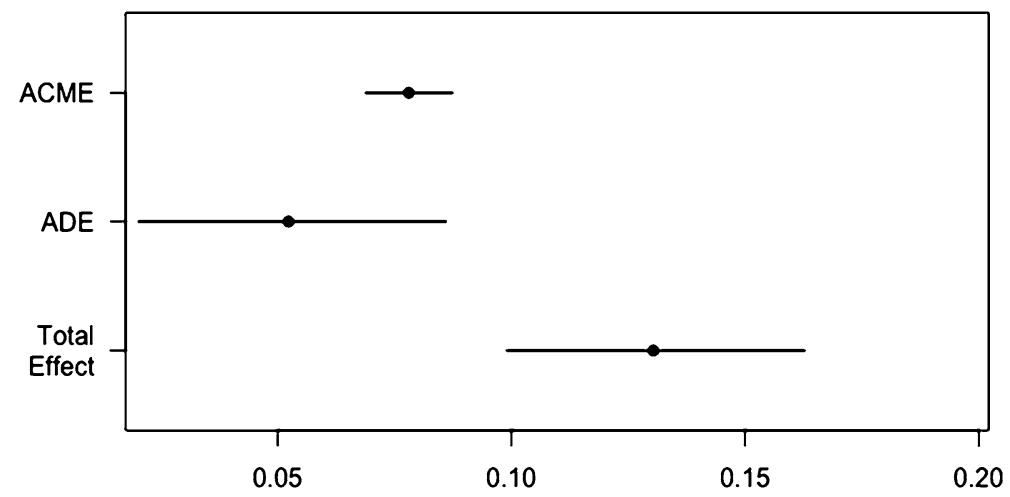

Fig. 1 The political consequences of self-insurance: evidence from a causal mediation framework. Notes: The figure is based on Model 3, Table 3. It presents three types of estimates: the average total effect, the average direct effect (ADE) and the average causal mediation effect (ACME). The vertical lines are $95 \%$ confidence intervals

access to savings on approval, i.e. the effect that does not flow through the economic optimism channel is also positive, and statistically significant at the $95 \%$ level $(0.05,95 \%$ CI $0.02,0.09)$. The effect of self-insurance that flows through the economic optimism mechanism, i.e. the average causal mediation effect (ACME) is also positive, and statistically significant, at around 0.08 (95\% CI 0.07, 0.09). What is more, the results from the mediation analysis suggest that the economic optimism mechanism accounts for as much as 60\% (95\% CI 0.47, 0.80), of the total effect of self-insurance on approval. This suggests that just over half of the total effect of self-insurance on evaluations of government operates through assessments of national economic performance.

Yet, we might be concerned that due to omitted variable bias, the results are driven by some other background characteristic of the individuals who can set money aside as savings, and which distinguishes them from individuals who cannot self-insure in the first place. To address such concerns, Section D3 in the Appendix replicates the main findings reported in Tables 2 and 3 using a nearestneighbour matching technique (NN matching). By using matching, we are able to estimate the effect of savings on economic optimism and approval by accounting for the covariates the predict having savings in the first place (Rubin 1973), such as social-economic positioning, employment status, risk attitudes, level of education, age and gender. Matching on these factors reduce threats to inference and reinforces confidence in our results. The results remain consistent. To summarize, the evidence presented thus far suggests that self-insurance increases economic optimism and ameliorates evaluations of government performance. By extension, it is possible to anticipate that in settings where a large part of the electorate can buffer the effects of economic dislocation, political support or evaluations of government performance would be less likely to decline as a result of an economic downturn. 


\section{Evidence from Russian Panel Data}

To explore some of the individual-level mechanisms developed in the main part of the argument in greater detail, and examine whether self-insurance effects on economic and political assessments hold when we consider types of self-insurance beyond savings, we turn to panel surveys from Russia. Survey evidence from Russia is comparatively rich and provides an unusual opportunity for further testing the mechanisms discussed in this paper in a illiberal context. What is more, reliance on private safety nets, such as networks of friends and family, land produce and barter has been traditionally very important in Russia (Rose et al. 2011). Russia also represents a classic example of hybrid, or competitive authoritarian regime, featuring the co-existence of legitimate and public competition with an organization and institutional field that renders this competition unfair (Magaloni 2006; Frye et al. 2017). Thus, in examining the Russian case in more detail, we can also delve deeper into the individual-level mechanisms that link self-insurance, economic and political assessments outside of democracies. Evidence employed for this second part of the analysis comes from the Russian Longitudinal Monitoring Survey (RLMS) (National Research University, NRU Higher School of Economics, HSE Demoscope et al. 2011). The dataset we employ here consists of four consecutive waves of surveys that span the period 2009-2012.

In repeated time-points, the RLMS questionnaire asks respondents to assess 'how long they think that they could live at the present level, without decreasing their expenditures and without any income, in the unpleasant situation in which all family members lost their income'. This question taps into respondents' own estimates of how long their household could get by, without earnings, if their current savings stopped. While this is a composite of objective access to private-safety nets and subjective assessments of their ability to weather an economic downturn (which could create noise in the measure) it is a measure extensively used in existing literature (e.g. Hacker et al. 2013). As an indicator of household economic buffers the measure the RLMS provides us with is broader than single-measure indicators (be it household access to savings and/or specific household assets) and captures households' ability to weather the effects of economic shocks by relying on a wide variety of risk-hedging assets. Concretely, respondents are invited to assess whether they could get by from less than a day to up to half a year. We recode this variable into a dummy. Coded as (1) are individuals who could get by for a month or more, and coded as (0) are those individuals who could only get by for less than a month. ${ }^{8}$ This measure is close to the 3-month threshold employed in comparative literature on the political consequences of self-insurance in the United States, yet the main results do not change if a continuous measure, which ranges from less than a week (1) to over a year (6) is used instead.

To examine how this measure of self-insurance relates to economic optimism, we rely on two additional measures that capture satisfaction with economic performance

\footnotetext{
8 See for example Hacker et al. (2014, S9) who show that the loss of three months of income (i.e. $25 \%$ of annual income loss) is expected to cause hardship for at least half of Americans.
} 
at the household and macro-economic levels. The first dependent variable is measured on a 5-point scale with higher values denoting more favourable assessments of household economic conditions. The second dependent variable relies on a survey item exclusively available in the 19th wave of the RLMS that was administered in 2010, and which asks individuals to assess, 'by their opinion, what is the percentage of unemployed people in their region'. This is a measure that has been previously used in influential studies of economic voting as a proxy of households' economic assessments (Ansolabehere et al. 2014). We use this item as an indicator of economic evaluations in general, and are not interested in individual deviations from the real unemployment rate in one's regions, or in whether citizens offer an accurate estimate of the unemployment rate. Consistent with existing literature, we interpret higher unemployment estimates to indicate that respondents are more concerned about how the economy is performing in their region.

As with the LITS surveys, the analysis relies on mixed effects linear models, with individuals clustered within household/years (Models 1 and 2), or just households (Models 3 and 4). In the case of household satisfaction, controls for previous-year satisfaction with household conditions. ${ }^{9}$ We do not lag the dependent variable when considering assessments of the unemployment rate, the sociotropic variable, as this item is only asked in a single year. In terms of demographic controls, we include an economic shock indicator that invites respondents to report whether they saw their working hours, or salary decline. We code this variable as (1) if respondents experienced the shock and (0) if otherwise. As the risk-exposure indicator is specific to work-force individuals, these models do not control for respondents' employment status. Table A2 in the Appendix provides summary statistics.

By controlling for previous-year economic satisfaction, Models 1 and 2 in Table 4 examine changes in people's satisfaction with household economic conditions, rather than absolute satisfaction. Model 1 in Table 4 uses a dichotomous measure of self-insurance, while Model 2 estimates the same, using a continuous measure instead. Models 3 and 4 respectively, which estimate self-insurance effects on subjective assessments of the regional unemployment rate, also control for the regional unemployment rate in respondents' regions. This indicator comes from Russia's Federal State Statistical Service (ROSSTAT). Evidence provided below suggests that individuals who were able to 'get by' for a longer period of time, consistently reported greater levels of economic satisfaction on the one hand, and lower estimates of the unemployment rate on the other. Turning to the last set of models for example, we see that the regional unemployment estimate of an individual who can 'get by' for one month or more is by 2 percentage points lower than that of their counterpart, who is only able to get by for less than a month, everything else equal.

Across all models, the experience of household economic shocks has the opposite effect of that of self-insurance. Cuts in respondents' salary, or working hours are

\footnotetext{
9 As we show in the Appendix., Table C1.2, the analysis also remains robust to the inclusion of random slopes for self-insurance and economic shocks. Table C1.3 shows that results presented in Models 1 and 2 below are robust to the inclusion of wave fixed-effects. Self-insurance effects on household, and macroeconomic assessments are finally robust to matching (Table D3.2).
} 
Table 4 Self-insurance and economic optimism: evidence from panel surveys in Russia. Source: Russian Longitudinal Monitoring Survey 2009-2012

(1)

Household economic assessments (2009-2012)

Self-insurance (dummy)

$0.304 * * *$
$(0.015)$

Self-insurance (continuous)

Economic assessments (lag)

Salary, hours reduced

Household income (log)

Age

Male

Education

Co-habiting

Regional unemployment

Constant

Log Likelihood

AIC

BIC

Individuals

Households*Years

(2)

$\begin{array}{ll} & 0.135^{* * *} \\ & (0.005) \\ 0.283^{* * *} & 0.276^{* * *} \\ (0.006) & (0.006) \\ -0.206^{* * *} & -0.201 * * * \\ (0.028) & (0.028) \\ 0.259^{* * *} & 0.246^{* * *} \\ (0.011) & (0.011) \\ 0.000 & -0.000 \\ (0.001) & (0.001) \\ 0.056^{* * *} & 0.053^{* * *} \\ (0.012) & (0.012) \\ 0.074 * * * & 0.069^{* * *} \\ (0.011) & (0.011) \\ -0.001 & 0.001 \\ (0.016) & (0.016)\end{array}$

$65,485.56$
Notes: Table entries are multilevel regression coefficients with standard errors in parentheses. Significant at the $,{ }^{*} \mathrm{p}<0.10, * * \mathrm{p}<0.05, * * * \mathrm{p}<0.01$ level
(3)

(4)

Unemployment estimate

$-2.284 * * *$
$(0.593)$

$-0.906^{* * *}$

$(0.215)$

$1.999^{* *}$

(0.840)

$-0.095$

$(0.461)$

0.013

(0.019)

$-3.094 * * *$

(0.394)

$-1.988^{* * *}$

(0.411)

0.112

(0.591)

$0.813^{* * *}$

(0.129)

34.457 ***

(0.818)

$-18,078.05$

$36,178.09$

$36,248.25$

4351

3010

$36,251.08$

4351

3010 (2010)

$65,682.16$

$\begin{array}{llll}23,458 & 14,591 & 3010 & 3010\end{array}$

robustly associated with more negative assessments of household economic conditions, and more pessimistic assessments of the regional unemployment rate. This implies that even in an illiberal political environment, as the one Russia featured this period, personal experiences of economic loss, could successfully translate into economically meaningful attitudes, and influence assessments of regional economic performance. Income, a classic predictor of economic evaluations and unemployment estimates in established democracies (e.g. Ansolabehere et al. 2014), fails to reach statistical levels of significance in both Models 3 and 4. This dovetails with existing research suggesting that outside of established democracies, individual 
heterogeneity in economic perceptions and political attitudes could be driven more by patterns of economic (in)security rather than economic disadvantage, as traditionally proxied by income (see also Brooks 2014).

Overall, results regarding self-insurance effects on economic optimism are consistent with cross-sectional evidence from the 2010 LITS surveys and in line with our theoretical propositions. They suggest that in Russia, just like in the rest of the region, the availability of a more robust portfolio of economic assets is robustly associated with economic optimism. ${ }^{10}$

\section{Alternative Explanations}

In this study, we have theoretically argued and empirically substantiated that private safety nets ameliorate government approval, and that a large part of this effect operates through the economic optimism channel. Yet, in many countries in Central-Eastern Europe, the Caucasus and Central Asia clientelism and corruption are rife. If incumbent supporters are the only ones with access to private safety nets (either because they are more well connected, or because they are more likely to receive handouts) the relationship between private safety nets and approval could be spurious. Similarly, one may be concerned that self-insurance ameliorates political support among only for voters who supported the government in the first place. To alleviate such concerns to the best of our ability, we turn to new datasets, and perform additional analysis. We introduce our findings below and present the results in Section E of the Appendix.

First, we show that controlling for risk exposure and economic performance, selfinsurance generates economic optimism and ameliorates government approval for voters who support the party in power and those who do not. As neither of the surveys examined so far included items that tap into respondents' partisanship, or affiliations towards the regime, we rely on a third unusually large dataset from Russia. The Russian Public Opinion Foundation Survey (FOM) of February 2011 (VCIOM 2011) comprises of a regionally, and nationally representative sample of over 50,000 respondents who were asked a range of opinion questions on economic and political issues. Just like the Life in Transition Surveys this survey includes a question that asks whether households have any savings, monetary or otherwise, but also includes an item tapping into respondents' vote intention. More specifically, respondents are asked to report 'whom they would vote for if a Parliamentary election was to be held this upcoming Sunday'. We recode this vote intention variable into a dummy that takes the value of (1) if respondents would vote for the United Russia, the ruling regime party, and (0) if they would not. In doing so, we investigate whether selfinsurance ameliorates economic and political assessments for both pro-government and opposition supporters. Overall, the analysis presented in Table E1 in the Appendix suggests that savings' holders are more likely to be satisfied with economic

\footnotetext{
10 Table C1.2 in Section C of the Appendix shows that the results are robust when we use random slopes for self-insurance and crisis exposure. Table D3.2 shows that findings are robust to matching.
} 
performance in their region, and to approve of Vladimir Putin's performance, regardless of whether they would support the party of power in upcoming elections or not. These results, we also show in Table E1B, are robust to nearest-neighbour matching. In sum, self-insurance colours economic and political assessments, and these effects hold for ruling party supporters, and the rest of the electorate.

To address concerns related specifically to clientelism, and self-insurance accumulated through vote-buying, Tables E2 and E3 in the Appendix presents the following analyses. First, and drawing on evidence documenting that vote-buying is greater in least democratic regions, we replicate the cross-sectional analysis by interacting the savings and democratic performance indicators. Results presented in Table E2 and Figure E1 in the Appendix suggest that self-insurance effects on approval differ very little across more or less liberal democracies. This finding suggests that in line with an economic voting mechanism, self-insurance encourages economic optimism and ameliorates approval across political systems and is in line existing literature documenting economic voting effects in democracies and autocracies (Lewis-Beck and Stegmaier 2008; Rosenfeld 2018; Chaisty and Whitefield 2012). Finally, we test for self-insurance effects on turnout. If households are able to set money aside because they receive handouts, or government payments in the form of positive inducements in order to vote, then they should also be more likely to report that they have turned out to vote for the parties who bought them off. Crosssectional analysis from the Life in Transition surveys presented in Table E3 of the Appendix provides evidence against this hypothesis. Being able to set money aside does not predict higher turnout, as the self-insurance coefficient is negative and fails to reach statistical levels of significance. Altogether, these findings do not seem in line with the argument that private safety nets result from clientelistic or vote-buying exchanges alone, and challenge the assumption that private safety nets matter only for ruling-party supporters.

\section{Conclusion}

Understanding which factors dampen citizens' ability to hold governments to account, especially during periods of macro-economic downturns, is a key question for scholars of elections. Using rich cross-sectional from 28 countries in Europe, the Caucasus, and combining it with panel data from Russia, we have examined how private safety nets affect economic and political assessments. Our results suggest that by allowing households to buffer against economic downturns, private safety nets systematically affect economic optimism and political support. These effects, which are robust when we control for household risk exposure, as well as countrylevel economic and democratic performance, suggest that self-insurance could at times help ill-performing incumbents escape blame for macro-economic dislocation.

Our findings speak to several literatures. Findings presented here reveal that selfinsurance has broad political ramifications, beyond the realm of social policy, and across more and less liberal regimes. In line with recent contributions in the economic voting literature (e.g. Pop-Eleches and Pop-Eleches 2012; Zucco 2013; Tilley et al. 2018), we have demonstrated that pocketbook assessments affect how citizens 
make sense of government performance. Results also contribute to debates of how private safety nets affect governance in illiberal democracies. By documenting selfinsurance effects on government approval across a range of liberal and illiberal democracies, we offer a an important individual-level explanation of how private safety nets, be it in the form of savings, or help from friends and relatives, could help extend government tenure (Ahmed 2012). More specifically, findings suggest that self-insurance could extend tenure not only by dampening demand for redistribution, but also by ameliorating government approval, even when economic performance is poor. Finally, evidence that private safety nets could aid incumbents has important implications for understanding governments' decision to promote policies and adopt rhetoric that encourage households to accumulate precautionary savings. Such policies, coinciding at times with serious cutbacks in state welfare spending, could possibly diminish electoral punishment. Exploring how government policies that encourage self-insurance affect saving decisions and the economic vote across more and less liberal democracies constitutes a fruitful avenue for future research.

Open Access This article is distributed under the terms of the Creative Commons Attribution 4.0 International License (http://creativecommons.org/licenses/by/4.0/), which permits unrestricted use, distribution, and reproduction in any medium, provided you give appropriate credit to the original author(s) and the source, provide a link to the Creative Commons license, and indicate if changes were made.

\section{References}

Ahmed, F. Z. (2012). The perils of unearned foreign income: Aid, remittances, and government survival. American Political Science Review, 106, 146-165.

Ahmed, F. Z. (2017). Remittances and incumbency: Theory and evidence. Economics and Politics, 29(1), $22-47$.

Anderson, C. J. (2007). The end of economic voting? Contingency dilemmas and the limits of democratic accountability. Annual Review of Political Science, 10, 271-296.

Ansell, B. (2014). The political economy of ownership: Housing markets and the welfare state. American Political Science Review, 108, 383-402.

Ansolabehere, S., Meredith, M., \& Snowberg, E. (2014). Mecro-economic voting: Local information and micro-perceptions of the macro-economy. Economics and Politics, 26(3), 380-410.

Becher, M., \& Donnelly, M. (2013). Economic performance, individual evaluations, and the vote: Investigating the causal mechanism. The Journal of Politics, 75(4), 968-979.

Brooks, S. (2009). Social protection and the market in Latin America: The Transformation of Social Security Institutions. New York: Cambridge University Press.

Brooks, S. (2014). Insecure democracy: Risk and political participation in Brazil. The Journal of Politics, 76(4), 972-985.

Campello, D., \& Zucco, C. (2015). Presidential success and the world economy. The Journal of Politics, 78(2), 589-602.

Campello, D., \& Zucco, C. (2017). Rewarding Merit or Luck? The Competency Signal in Comparative Perspective. Paper presented at the American Political Science Annual Conference, San Francisco, August 31-September 3.

Carlin, R. E., \& Hellwig, T. T. (2015). The Other Side of Neoliberalism: Policy Regimes and Economic Accountability in Latin America. Retrieved from http://ostromworkshop.indiana.edu/files/pdfs/serie spapers/2015f_c/hellwigpaper.pdf.

Carlin, R. E., Love, G. J., \& Martinez-Gallardo, C. (2014). Cushioning the fall: Scandals, economic conditions and executive approval. Political Behaviour, 37, 109-130.

Carroll, C. D. (1997). Buffer-stock saving and the life cycle/permanent income hypothesis. The Quarterly Journal of Economics, CXII, 1-55. 
Carroll, C. D., \& Kimball, M. S. (2008). Precautionary savings and precautionary wealth. In S. N. Durlauf \& L. Blume (Eds.), The new Palgrave dictionary of economics. New York: Palgrave Macmillan.

Chaisty, P., \& Whitefield, S. (2012). The effects of the global financial crisis on russian political attitudes. Post Soviet Affairs, 28(2), 187-208.

Cheng, L.-L., \& Gereffi, G. (1994). The informal economy in East Asian development. International Journal of Urban and Regional Research, 18(2), 194-219.

Clark, A. \& Lelkes, O., 2005. Deliver us from Evil: Religion as insurance. PSE Working Papers n2005-43.

Colton, T. J., \& Hale, H. E. (2009). The putin vote: Presidential electorates in hybrid regime. Slavic Review, 68, 473-503.

Cordova, A. (2009). Methodological note: Measuring relative wealth using household asset indicators. Americas Barometer Insights, 6, 1-9.

De la Garza, R. \& Hazan, M., 2003. Looking Backward, Moving Forward: Mexican Organisations in the US as Agents of Incorporation and Dissociation-Research Report 6023,

Diaz, A. (1993). Restructuring and the New Working Classes in Chile: Trends in Waged Employment, Informality and Poverty 1973-1990, New York.

Doyle, D. (2015). Remittances and social spending. American Political Science Review, 109(4), 785-802.

Duch, R. M., \& Stevenson, R. T. (2008). The economic vote: How political and economic institutions condition election results. Cambridge: Cambridge University Press.

EBRD. (2011). Life in Transition After the Crisis. EBRD Report.

Ehrlich, I., \& Becker, G. S. (1972). Market insurance, self-insurance, and self-protection. Journal of Political Economy, 80, 623.

Escribà-Folch, A., Meseguer, C., \& Wright, J. (2015). Remittances and democratization. International Studies Quarterly, 59(3), 571-586.

Freedom House. (2010). Freedom in the world. Retrieved April 18, 2017. https://freedomhouse.org/repor t/freedom-world/freedom-world-2010.

Frye, T., Gehlbach, S., Marquardt, K., \& Reuter, O. (2017). Is Putin's popularity real? Post Soviet Affairs, 33(1), 1-15.

Gill, I. S. \& Ilahi, N. (2000). Economic insecurity, Individual Behavior and Social Policy, Washington D.C.

Gingrich, J., \& Ansell, B. (2012). Preferences in context: Micro preferences, macro contexts, and the Demand for Social Policy. Comparative Political Studies, 45(12), 1624-1654.

Greskovits, B. (1998). The political economy of protest and patience: Political and economic reforms in Eastern Europe and Latin America. Budapest: Central European University Press.

Hacker, J. S., Rehm, P., \& Schlesinger, M. (2013). The insecure American: Economic experiences, financial worries, and policy attitudes. Perspectives on Politics, 11(1), 23-49.

Hacker, J. S., et al. (2014). The Economic Security Index: A new measure for research and policy analysis. Review of Income and Wealth, 60(May), S5-S32.

Harknett, K. (2006). The relationship between private safety nets and economic outcomes among single mothers. Journal of Marriage and Family, 68(1), 172-191.

Healy, A., \& Malhotra, N. (2012). Retrospective voting reconsidered. Annual Review of Political Science, 16(1), 285-306.

Hernandez, E., \& Kriesi, H. (2015). The electoral consequences of the financial and economic crisis in Europe. European Journal of Political Research, 55(2), 203-224.

Imai, K., Keele, L., \& Tingley, D. (2010a). A general approach to causal mediation analysis. Psychological Methods, 15(4), 309-334.

Imai, K., Keele, L., \& Yamamoto, T. (2010b). Identification, inference and sensitivity analysis for causal mediation effects. Statistical Science, 25(1), 51-71.

Johnston, R. (2006). Party identification: Unmoved mover or sum of preferences? Annual Review of Political Science, 9(1), 329-351.

Kriesi, H. (2012). The political consequences of the financial and economic crisis in Europe: Electoral punishment and popular protest. Swiss Political Science Review, 18(4), 518-522.

Lewis-Beck, M. S., \& Nadeau, R. (2011). Economic voting theory: Testing new dimensions. Electoral Studies, 30, 288-294.

Lewis-Beck, M. S., \& Stegmaier, M. (2008). The economic vote in transitional democracies. Journal of Elections, Public Opinion \& Parties, 18(3), 303-323.

Lewis-Beck, M. S., \& Stegmaier, M. (2009). American voter to economic voter: Evolution of an idea. Electoral Studies, 28, 625-631. 
Life in Transition Survey II. (2010). European Bank for Reconstruction and Development. https://www. ebrd.com/cs/Satellite $? \mathrm{c}=$ Content $\& \mathrm{cid}=1395236498263 \& \mathrm{~d}=$ Mobile $\&$ pagename $=$ EBRD $\% 2 \mathrm{FCon}$ tent $\% 2$ FContentLayout.

Magaloni, B. (2006). Voting for autocracy: Hegemonic party survival and Its demise in Mexico. Cambridge: Cambridge University Press.

McMann, K. M. (2006). Economic autonomy and democracy: Hybrid regimes in Russia and Kyrgyzstan. Cambridge: Cambridge University Press.

Meagher, K. (1995). Crisis, informalization and the urban informal sector in Sub-Saharan Africa. Development and Change, 26, 259-284.

Mody, A., Ohnsorge, F. \& Sandri, D., 2012. Precautionary Savings in the Great Recession, IMF Working Paper.

Nadeau, R., Foucault, M., \& Lewis-Beck, M. S. (2011). Assets and risk: A neglected dimension of economic voting. French Politics, 9(2), 97-119.

National Research University. (2011). "Higher School of Economics" and OOO "Demoscope" together with Carolina Population Center, University of North Carolina at Chapel Hill and the Institute of Sociology of the Federal Center of Theoretical and Applied Sociology of the Russian Academy of Sciences. 2011. "Russia Longitudinal Monitoring survey, RLMS-HSE".

Pacek, A. C., \& Radcliff, B. (1995). Economic voting and the welfare state: A cross-national analysis. Journal of Politics, 57(1), 44-61.

Persson, M., \& Martinsson, J. (2016). Patrimonial economic voting and asset value-New evidence from taxation register data. British Journal of Political Science. https://doi.org/10.1017/S000712341 6000181.

Pop-Eleches, C., \& Pop-Eleches, G. (2012). Targeted government spending and political preferences. Quarterly Journal of Political Science, 7(3), 285-320.

Popova, O. (2014). Can religion insure against aggregate shocks to happiness? The case of transition countries. Journal of Comparative Economics, 42, 804-818.

Rehm, P., Hacker, J. S., \& Schlesinger, M. (2012). Insecure alliances: Risk, inequality, and support for the welfare state. American Political Science Review, 106, 386-406.

Rose, R., Mishler, W., \& Munro, N. (2011). Popular support for an undemocratic regime: The changing views of Russians. Cambridge: Cambridge University Press.

Rosenfeld, B. (2018). The popularity costs of economic crisis to ruling parties in an electoral authoritarian regime. American Journal of Political Science, 62(2), 382-397.

Rubin, D. (1973). Matching to remove bias in observational studies. Biometrics, 29(1), 159-184.

Singer, M. M. (2011). Who says "It's the economy"? Cross-national and cross-individual variation in the salience of economic performance. Comparative Political Studies, 44, 284-312.

Singer, M. M., \& Carlin, R. E. (2013). Context counts: The election cycle, develop-ment, and the nature of economic voting. Journal of Politics, 75(3), 730-742.

Stokes, S. C. (2001). Mandates and democracy: Neoliberalism by surprise in Latin America. New York: Cambridge University Press.

Tertytchnaya, K., de Vries, C. E., Solaz, H., \& Doyle, D. (2018). When the money stops: Fluctuations in financial remittances and incumbent approval in Central Eastern Europe, the Caucasus and Central Asia. Forthcoming in the American Political Science Review.

Tilley, J., Neundorf, A., \& Hobolt, S. B. (2018). When the pound in people's pocket matters: How changes to personal financial circumstances affect party choice. Journal of Politics, 80(2), 555-569.

Treisman, D. S. (2011). Presidential popularity in a hybrid regime: Russia under Yeltsin and Putin. American Journal of Political Science, 55(3), 590-609.

VCIOM, 2011. Public Opinion Foundation Surveys.

Weatherford, S. M. (1983). Economic voting and the "Symbolic Politics" argument: A reinterpretation and synthesis. American Political Science Review, 77, 158-174.

World Bank. (2011). The job crisis. Washington D.C.: World Bank.

Zucco, C. (2013). When payouts pay off: Conditional cash transfers and voting behavior in Brazil 20022010. American Journal of Political Science, 57(4), 810-822. 